\title{
Productivity of Horticulture in Remote Tribal Areas of Andhra Pradesh
}

\author{
Appalanaidu Pappala \\ Guest Faculty, Department of Anthropology, \\ Andhra University, Visakhapatnam, Andhra Pradesh, India
}

\begin{abstract}
The present study reveals that horticultural crops i.e. mango, guava, banana, pineapple, etc. in remote agency area of Andhra Pradesh state, productivity of horticulture helps to reduce an extensive deforestation. The qualitative data collected from 45 key informants both sexes belonging to tribal population of the Kurnool, Prakasam, Visakhapatnam, Vizianagaram and Srikakulam districts. For data collection, observation and interview methods employed.
\end{abstract}

KEYWORDS: Horticulture, Deforestation, Tribal Area, Andhra Pradesh.

\section{INTRODUCTION}

Productivity is able to produce large amount of crops, goods, or other commodities. The rate of production of new biomass by an individual, population, or community; the fertility or capacity of a given habitat or area. The horticulture sectors account for about 13 per cent of gross cropped area (192.8 million hectares) in India. Its share is about 37 per cent of the total exports of agricultural commodities. The share of Horticulture with respect to Agriculture has gone a huge change with the Government of India framing and giving much importance in horticulture sector in the five year plan. The production of horticulture crops consisting of five varieties of crops namely fruit, vegetables, potato and tuber, ornamental, medicinal and aromatic, spices and plantation of which the maximum production share is of vegetables i.e. 60 per cent and next is the fruits with 30 per cent and the other remaining share of crops are flowers, spices and plantation crops.

India has witnessed voluminous increase in horticulture production. The table- 1 shows the detail of plan outlay allocation of share from $9^{\text {th }}$ plan $(3.9 \%)$ to $12^{\text {th }}$ plan $(4.6 \%)$. On the other hand Annual growth trends of horticulture production in India has been taken from 2010-11 to 2014-15 and as a whole it is found that area and production of horticulture crops to some extend keep on moving up and down slightly. Fruits and vegetables account for nearly $90 \%$ of total horticulture production in the country. However the nature of horticulture crops being such it's not easy to make assessment of their production. These crops, especially vegetables are grown in small plots, fields or in the back of the houses, do not have single harvesting in most of the cases which makes their assessment difficult.

Table-1: Five Year Plan-wise share of Horticulture in Agriculture

\begin{tabular}{|c|c|c|}
\hline \multirow{2}{*}{ Years } & \multicolumn{2}{|c|}{ Plan outlay } \\
\cline { 2 - 3 } & Agriculture \& allied activities ('O00') & Horticulture ('000') \\
\hline 9th plan (1997-2002) & Rs.37546 & Rs.1453 (3.9\%) \\
\hline 10th plan (2002-07) & Rs.58031 & Rs.5025 (8.5\%) \\
\hline 11th plan (2007-12) & Rs.136381 & Rs.15800 (11.6\%) \\
\hline 12th plan (2012-17) & Rs.363273 & Rs.16840 (4.6\%) \\
\hline
\end{tabular}

Source: Horticulture Statistics Division, DAC\&FW.

During 2016-17, the production of horticulture crops was about 295.2 million tons from an area of 24.9 million hectares (DAC\&FW, 2016). Significant progress has been made in area expansion resulting in higher production. Over the last decade, the area under horticulture grew by about 3 per cent and annual production increased by 5.4 per cent. The production of vegetables has increased since 1991-92 (58.5 million tons) to 2016-17 (175 million tons).

Table-2: Distribution of horticulture crop's productivity per Ha. (MTs)

\begin{tabular}{|c|c|c|}
\hline Crop & $\begin{array}{c}\text { Present productivity } \\
\text { per Ha. (MTs) }\end{array}$ & $\begin{array}{c}\text { Maximum productivity } \\
\text { per Ha.(MTs) }\end{array}$ \\
\hline Mango & 8.6 & 12.20 (Uttar Pradesh) \\
\hline Cashew & 0.68 & 1.26 (Maharastra) \\
\hline Pomegranate & 10.00 & 11.40 (Karnatka) \\
\hline Banana & 35.00 & 62.00 (Maharastra) \\
\hline Vegetables & 16.80 & 30.40 (Tamilnadu) \\
\hline
\end{tabular}


It can be well understood by looking into the table-2 for distribution of horticulture crop's productivity per Ha. (MTs). Many horticulture crops have multiple pickings in a single season. Similarly many fruit trees are scattered, which do not count for assessment. The reasons might be due to seasonality variation of cropping pattern and other factors.

The table-3 clearly shows the percentage share of production of horticultural crops. The production of horticulture crops consisting of five varieties of crops of which the maximum production share is of vegetables i.e. 60 per cent and next is the fruits with 30 percent and the other remaining share of crops are flowers, spices and plantation crops.

Table-3: Percentage share of production of various Horticulture crops

\begin{tabular}{|c|c|c|c|c|c|c|}
\hline S. No & Year & Fruits & Vegetables & Flowers & Plantation & Spices \\
\hline $\mathbf{1}$ & $2010-11$ & 31.1 & 61.0 & 0.7 & 5.0 & 2.2 \\
\hline $\mathbf{2}$ & $2011-12$ & 29.7 & 60.8 & 0.9 & 6.4 & 2.3 \\
\hline $\mathbf{3}$ & $2012-13$ & 30.2 & 60.3 & 1.0 & 6.3 & 2.1 \\
\hline $\mathbf{4}$ & $2013-14$ & 32.1 & 58.7 & 1.0 & 5.9 & 2.1 \\
\hline $\mathbf{5}$ & $2014-15$ & 31.3 & 59.4 & 1.1 & 6.0 & 2.1 \\
\hline
\end{tabular}

Source: Horticulture Statistics Division, DAC\&FW.

\section{Horticulture in Andhra Pradesh}

Andhra Pradesh is the second largest producer of horticulture crops. Table- 4 \& 5 shows the status of horticulture, area of extension and production in the state. Mango and citrus are the major fruit crops in the Kurnool region and Mango, banana, citrus, guava and custard apple are important fruit crops in the Nellore and Prakasam region. In Chittoor district, mango occupies nearly 97 percent of the total area under fruits, while in Nellore, citrus accounts for 58 per cent of the total area under fruits, followed by mango (39\%).

Table-4: Status of Horticulture in Andhra Pradesh

\begin{tabular}{|c|c|c|c|}
\hline \multirow{2}{*}{ SI. No. } & \multirow{2}{*}{ Sector / Crop } & Production ( in 000'MTs) \\
\cline { 3 - 4 } & & INDIA & A.P. \\
\hline $\mathbf{A .}$ & SECTOR & & \\
\hline $\mathbf{1}$ & Spices & 4102.7 & 1235.2 \\
\hline $\mathbf{2}$ & Fruits & 63503 & 10722.3 \\
\hline $\mathbf{3}$ & Flowers & 654.08 & 88.81 \\
\hline $\mathbf{B}$. & CROP & & \\
\hline $\mathbf{4}$ & Mango & 13792.1 & 3865.2 \\
\hline $\mathbf{5}$ & Citrus & 7574.4 & 2997.9 \\
\hline $\mathbf{6}$ & Papaya & 2685.9 & 1123.4 \\
\hline $\mathbf{7}$ & \multicolumn{5}{|c|}{ Tomato } & 10260.6 & 1579 \\
\hline \multicolumn{4}{|c|}{ Source: NHB Database 2007-08 } \\
\hline
\end{tabular}

Table-5: Area \& Production Of Horticulture Crops

\begin{tabular}{|c|c|c|c|}
\hline $\begin{array}{c}\text { S.. } \\
\text { No. }\end{array}$ & $\begin{array}{c}\text { Crop } \\
\text { Category }\end{array}$ & $\begin{array}{c}\text { Area } \\
\text { (in Lakh } \\
\text { Ha.) }\end{array}$ & $\begin{array}{c}\text { Production } \\
\text { (in Lakh } \\
\text { MTs.) }\end{array}$ \\
\hline $\mathbf{1}$ & Fresh Fruits & 9.36 & 131.65 \\
\hline $\mathbf{2}$ & $\begin{array}{c}\text { Plantation } \\
\text { Crops }\end{array}$ & 3.86 & 6.76 \\
\hline $\mathbf{3}$ & $\begin{array}{c}\text { Vegetables \& } \\
\text { Tuber Crops }\end{array}$ & 3.25 & 52.67 \\
\hline $\mathbf{4}$ & Flowers & 0.19 & 1.25 \\
\hline $\mathbf{5}$ & Spices & 3.03 & 11.51 \\
\hline $\mathbf{6}$ & $\begin{array}{c}\text { Medicinal \& } \\
\text { Aromatic Plants }\end{array}$ & 0.20 & 0.77 \\
\hline & TOTAL & 19.89 & 204.61 \\
\hline
\end{tabular}

Source: NHB Database 2007-08

\section{Horticulture in Tribal areas}

Agriculture in Tribal areas including horticulture has been a subject of great controversy for quite some time now. All people agree that it is wasteful and arduous. It denudes the hills of their rich forest wealth, causes soil erosion and eventually results in scanty rainfall, and this in turn progressively reduces the crop yields. Everyone wants this extravagant practice to be replaced by more efficient ways of growing crops. Government of India and State of Andhra Pradesh introduced many schemes like 'Podu Rehabilitation Scheme (PRS)' initiated to improve the economic condition of the tribals by raising fruit plants of low gestation period along with timber and other economic plants. The objective is both to improve the economic condition and stabilize the tribals and to generate forest growth and conserve soil fertility. An intensive programme for conversion of 'podu' lands into horticulture was taken up with a hope that the horticultural crops (fruits) would yield continuous income. Both central and states governments view in recent years is, however, different. In Andhra Pradesh along it is estimated that about 63 thousand hectares of podu cultivation exists in the agency areas (Ministry of Forest affairs, 2014).

The research studies conducted in the region proved that returns from the horticultural crops are found to be quite encouraging as compared to shifting cultivation. In the hilly areas, horticultural crops are considered to be a viable alternative to shifting cultivation practices (CESS., 2016; Rao, PT., 2014; Srinivasa Rao et al., 2010; Asati B. S. and Yadav D. S., 2004; Sudha, M and Y.V.R. Reddy., 1992; Subramanyam, K.V., 1989; Sudha, M and Y.V.R. Reddy., 1988; Singh, M. K., 1982; Palani Swami, S and V. Rajagopalan., 1978; Saha, 1973 and others). The present study reveals that productivity of horticulture in the agency area is helps to reduce extensive deforestation. The study concentrated mainly five districts of Andhra Pradesh i.e., Kurnool, Prakasam, Visakhapatnam, Vizianagaram and Srikakulam were selected, data collected from 45 key informants both sexes belonging to tribal population. Anthropological fieldwork traditional methods were employed.

Majority of tribals in the agency areas follow shifting cultivation (podu). Depletion of the forest cover through 'podu' cultivation leads to soil erosion, deforestation, silting reservoirs, and even declining or erratic rainfall. They regard the practice of shifting cultivation as an organic response to certain geographical conditions of mountainous tribal areas. In their opinion the correct approach to this problem lies not in merely condemning it as an evil practice but regarding it as an agricultural practice evolved as a reflex to the physiographical character of land. According to them the widely held notion that horticulture is the best cultivation of tribal agriculture to arrest extensive deforestation. 
The aim of horticultural programme in the agency area is to capture extensive deforestation, soil erosion and the resultant ecological imbalance. in order to develop 'podu' areas and to restore ecological imbalance, it is proposed to grow fruit plants in all the areas were soil, climate, rainfall and slopes are favourable. The Integrated Tribal Development Agencies (ITDAs) have started introducing horticultural crops (mango, cashew, guava, pomegranate, citrus, etc). However, without ascertaining the suitability and adoptability of these crops to the climate of the agency area. This led to a number of problem in the performances of the fruit crops in these crops. The problems encountered in the raising of different fruit crops as reported and observed, with tentative suggestions.

\section{Mango}

Hill mangos grow all over the agency areas indicating their excellent adoptability to the area. The soils in which mango are raised are mostly infertile because of continued 'podu' cultivation loading to stunted growth (Figure-1). Slow growth of the plants and late rip-ending of the fruits may be due to unfavourable temperature. Though mango is found to grow at elevations of $1200 \mathrm{~m}$, but beyond $600 \mathrm{~m}$, it cannot give commercial returns. mango requires a lot of sunshine, which is not available in the hills. The best climate for mango has rainfall of $75-250 \mathrm{~m}$ in the four months (June to September) followed by eight months of dry season and particularly stress prior to its flowering; which are not available, since agency areas are prone to receive. During the study, it was suggested by horticultural officer, ITDA Paderu, to try Alphonso variety from Maharashtra. Early varieties like Panakalu, Rasalu, Navanootham, Banginapalli, etc., may also be tried.

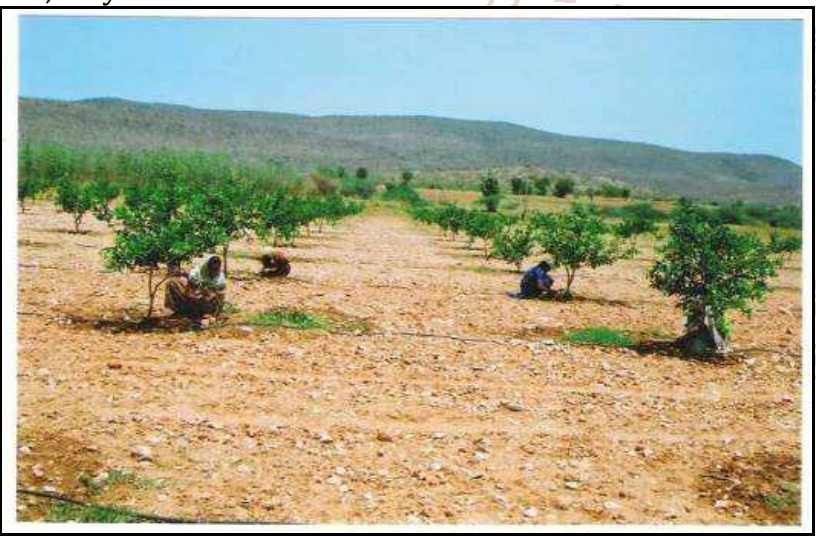

Figure-1: Hill mangos grow in the agency area

\section{Cashew}

Integrated Tribal Development Agencies (ITDAs) have taken up cashew mix cropping also the agency areas. the elite seed of Bapatla varieties is procured and distributed to beneficiaries. In Seethampeta agency cashew is taken up in a big way. Though the trees are putting forth good vegetative growth and flowering, the fruiting is not good. It is reported that the kernel inside the nut is not forming well. All this have led to poor performance of cashew in the agency areas. It may be suggested to limit the cashew plantation to lower elevations say up to $600 \mathrm{~m}$. It may also be suggested to introduce west-coast varieties of cashew which are accustomed to such type of climate.

\section{Citrus}

In the agency areas a mondarin (citrus reticulata) locally called 'kamala' is raised, particularly as a shade tree for coffee. The kamalas were tried at Aruku valley with little success. the growth and yield of the sweet citrus (orange) are good but the fruit are sour insipid though juicy because of high humidity at higher elevation. Further these is heavy incidence of fruit sucking month. Sweet orange is well suited for arid plains. Lemons are performing well but there is neither demand nor market for the fruits.

\section{Pomegranate}

It is grouped under sub-tropical fruits and has now gained importance in dry-land horticulture. Pomegranate favours a semi arid climate. It is putting good vegetable growth, the fruits are small to medium in size, but fruit borer is severe. Under the agency conditions these are not suitable as they put forth much vegetative growth and loss fruit.

\section{Guava}

The popular variety Allahabad Safeda and Lucknow-49 were seen performing well in the agency areas surveyed. Of all the fruit crops guava was found to be without any problem. However, lack of market for the fruits is the only problem reported. Because of undulated terrain transport is also a problem. So these two factors limit further expansion of the crop.

\section{Banana}

It has no problems except poor yield so not economical. Amruthapani, a variety of banana performs well in the agency areas. So this can be continued. In Kusumi village of Seethampeta agency hill banana is raised up to the top of hills intercropped with Cashew, Pineapple, and Turmeric and is without serious problems.

Figure-2: Banana grows in the agency area

\section{Jackfruit}

Solitary and stray plants of Jack are soon everywhere at different elevations in the agency areas. Jack is at home and is performing well. But again its transport and marketing are the limitations for its expansion. Further being highly perishable it cannot be transported for long distances.

\section{Other fruits}

Temperate fruits like apple, pear and peach failed to perform satisfactorily as soon at horticultural nursery and training centres at Araku Valley and Kottavalasa. This may be due to absence of distinct winter and on-availability of adequate chilling period as the elevations are medium, whereas they require an elevation more than $1500 \mathrm{~m}$. Out of the many subtropical fruits only Litchi has given good performance. However, it has no consumer performance and market. 


\section{Minor Forest Crops}

Tamarind, Soap nut, etc. which are now scattered in forests may be tried on garden scale at suitable locations on longterm basis.

\section{Beverage Crops}

Among beverage crops Coffee is excellent. Taking up of the coffee plantation in the 'podu' lands helps in conservation of existing forest growth and ecology. The problem of soil erosion is also tackled effectively as coffee is grown across the slopes. Coffee plants provided humus by shedding the leaves, while the roots act as soil binders. However, coffee requires high investment and management, hence not feasible with the tribal people, whose land holdings are small (1.5 acres per household). But this can be overcome by farming cooperative societies with tribal people which also helps in expansion of the present area. Besides coffee, Cocoa and Vanilla may be tried.

\section{Spices, Condiments, etc.}

Among the spices, Pepper is performing well at Chintapalli Agency, Nallamala Hills and also in some coffee gardens. Ginger and turmeric are observes to perform well, particularly as intercrops. Instead of local types improved types can be introduced.

\section{Vegetables}

It is reported that almost all the important vegetables such as tomato, brinjal, chillies, lady fingers, cauliflower, cabbages, etc. are coming up well and economical potato is excellently well. Additionally seed production of winter vegetables may also be tried.

\section{Medicinal Plants}

Forests in agency areas are rich in medicinal plants, which may be explored for large scale cultivation.

\section{Conclusion}

Generally speaking as the agency areas are thickly forested, cool and humid, shade-based cropping systems are more suitable instead of sole cropping systems. This permits less risk, in the sense of one fails, the other may provide income to the grower. Further, as the crops raised on denuded 'podu' lands, which lack organic matter fertility and water holding capacity. Finally this study show the horticultural crops that are both to improve the economic condition and stabilize the tribals and to regenerate forest growth (forestation) and conserve soil fertility.

\section{References}

[1] Asati B. S. and Yadav D. S. (2004). Diversity of horticultural crops in Northeastern region. ENVIS Bulletin: Himalayan Ecology, 12: 1-11.

[2] CESS (2016). "Commission on Inclusive and Sustainable Agricultural Development in Andhra Pradesh", submitted to Government of Andhra Pradesh.

[3] DAC\&FW (2016). Horticulture Statistics Division. Ministry of Agriculture \& Farmers Welfare, Government of India.

[4] Ministry of Forest affairs (2014). Podu cultivation. Government of India, New Delhi.

[5] NHB (2007-08). Baseline Data on Area, Production and Productivity of Horticulture. www.isec.ac.in/BaselineDataOnHorticulture\%20Crops. pdf

[6] Palani Swami, S and V. Rajagopalan. (1978). Labour requirement of crops. Madras Agri. Journal 65(8): 520523.

[7] Rao, PT (2014) "Tribal Land Alienation in Andhra Pradesh", Journal of Rural Development, Vol 33, number 3, pp 329-342

[8] Singh, M. K. (1982). Production and marketing of vegetables around Hyderabad. M. Sc. (Agri. Thesis APAU, Hyderabad.

[9] Srinivasa Rao, Ch and Venkateswarlu, B and Wani, S P and Sahrawat, KL and Dixit, S and Kundu, S and Devi, K G and Rajesh, C and Pardasaradhi, G (2010) Productivity enhancement and improved livelihoods through participatory soil fertility management in Tribal Districts of Andhra Pradesh. Indian Journal of Dryland Agriculture Research and Development, 25 (2). pp. 23-32. ISSN 0971-2062

[10] Subramanyam, K.V. (1989). Economics of cultivation of horticulture crops in South India. Technical Bulletin No. 7 IIHR, Banglore p. 44-61

[11] Sudha, M and Y.V.R. Reddy. (1988). Economics of sweet orange cultivation Indian Horticulture 33 (3):27629.

[12] Sudha, M and Y.V.R. Reddy. (1992). Marketing of Guava. Indian Horticulture, 37 (1):25627. 